period of one to two thousand years and a coefficient three or four times that of Hansen's, and he expressed doubts regarding the existence of tidal retardations in the rotation of the earth. In a number of other papers he dealt with similar subjects, showing the presence of terms in the moon's motion due to the direct action of the planets, the value of the long inequality due to the disturbing action of Mars, lunar perturbations arising from Jupiter, etc. In the last point he was many years ahead of all other workers in the same field. His research in dynamical astronomy was not confined to lunar work and his versatile mind was able to turn to other branches. As one example, reference may be made to an important paper in 1879 with the title "On the General Solution of the Problem of Disturbed Elliptic Motion". An example of his interest in observational astronomy is shown by his work with a Newtonian reflector of $9 \frac{1}{8}$-inch aperture on the satellites of Saturn. $\mathrm{He}$ communicated his results to the Royal Astronomical Society in 1876 and dealt with his observations of Titania and Oberon, which he was just able to observe under favourable conditions.

In 1882 Nevill went to Natal to observe the transit of Venus, and as a result of the interest aroused in astronomy, a semi-public observatory was established through the generosity of certain residents in Durban assisted by the Corporation. Later, when this was taken over by the Government of Natal, Nevill was appointed the first director. Not only did he carry out the ordinary routine work of the observatory, but he also conducted research in his favourite subject and deduced new values for lunar elements. Reference has been made earlier to the results of some of this research. Unfortunately many of his results, including his lunar tables, still await publication. After his retirement from the observatory he does not appear to have done very much work, and the last paper that he contributed to the Monthly Notices was in May 1915 entitled, "On the Conjunction of Stars with the Moon, recorded by Ptolemy'. He was elected a fellow of the Royal Astronomical Society in 1873 and a fellow of the Royal Society in 1908.

\section{Mr. B. D. Porritt}

THE death of Mr. B. D. Porritt, on January 28, came as a shock to his friends despite the long illness that had foreshadowed it.

Mr. Porritt was born of Yorkshire parents in Canada in 1884, and was educated at the Whitgift Grammar School, Croydon; at University College, London, where he graduated in ehemistry in 1908 ; and at Heriot Watt College, Edinburgh. He joined the North British Rubber Co., Ltd., where he was chief chemist in 1912 and research superintendent in 1916. He left the Company in 1920 to assume the directorship of the Research Association of British Rubber Manufacturers, then inaugurated under the co-operative research scheme of the Department of Scientific and Industrial Research.

The chemistry and physics of the rubber industry in 1908 was much more primitive and ill-informed than to-day, and Mr. Porritt had a wealth of problems before him from the beginning. In the early years, he made useful contributions to analytical and testing methods for rubber. This interest continued throughout his life, for in later years he concentrated an enormous amount of fine detail work on the standardization of testing methods, and was a leading spirit in establishing the Rubber Industry Committee of the British Standards Institution.

Observations of a more fundamental nature were made, as early as 1920-21, on the then unsuspected photopolymerization of rubber solutions, and on the role of oxygen in the mastication of crude rubber. Both these subjects have since received much development in other hands.

Another early interest, which he was able to pursue at length for himself, was the study of the surface breakdown of hard rubber under the influence of light. He contributed also many observations on the swelling of rubber in non-aqueous liquids and on the factors influencing that obscure phenomenon. One of his last interests was the production of crude rubber in the form of fine powder, and the utilization of the new product in novel processes.

By way of a hobby, Mr. Porritt was the British rubber industry's historian, and his "Early History" has long been the classic source for all subsequent writers in this particular field.

The story of B. D. Porritt would be quite incomplete without stress being laid on his tireless work in promoting co-operative research. He commenced in and with the Rubber Research Association when the industry's interest was so lukewarm that only fifteen member firms supported the idea; he left it at his death with more than 170 member firms. This progress and success was due mainly, if not wholly, to his untiring efforts in promoting the co-operative principle, and to the sound work of the organization which he built up. His flair for organization, indeed, extended in many directions. He made a notable success of the Rubber Exhibition at the London Science Museum in 1934-35, and was a leading promoter of the Rubber Technology Conference of the Institution of the Rubber Industry in 1938.

$\mathrm{He}$ was author of a small book, "Chemistry of Rubber", in 1913, and co-author of the now wellknown reference handbook, "Rubber, Physical and Chemical Properties", in 1935.

\section{T. R. DAwson}

\section{WE regret to announce the following deaths:}

Mr. K. E. Heesom, inspector of mines, Sierra Leone, on February 11, aged forty years.

Prof. J. H. Michell, F.R.S., professor of mathe matics during 1923-1928, and honorary research professor of mathematics since 1928 in the University of Melbourne, on February 3, aged seventy-six years.

Prof. E. Soler, emeritus professor of theoretical geo. desy in the University of Padua, vice-president of the International Association of Geodesy, on January 24.

Prof. Margaret Floy Washburn, professor of psychology at Columbia University, author of "The Animal Mind", aged sixty-eight years. 